\title{
Legal Abortion Worldwide in 2008: Levels and Recent Trends
}

\author{
By Gilda Sedgh, \\ Susheela Singh, \\ Stanley $K$. \\ Henshaw and \\ Akinrinola Bankole
}

Gilda Sedgh is senior research associate, Susheela Singh is vice president for research, Stanley K. Henshaw is senior fellow and

Akinrinola Bankole is director of international research-all with the Guttmacher Institute, New York.

CONTEXT: Periodic assessments of abortion incidence are essential for monitoring trends in unintended pregnancy and gaps in contraceptive services and use.

METHODS: Statistics and estimates of legal induced abortions in 2008 were compiled for 64 of the 77 countries in which legal abortion is generally available; these 64 are home to $98 \%$ of women aged $15-44$ who live in the countries eligible for inclusion. Data sources included reports or completed questionnaires from national statistical offices and nationally representative surveys. The completeness of official figures was assessed by in-country and regional experts. Trends since 1996 and 2003 were examined.

RESULTS: Of the 77 countries with liberal abortion laws, 36 are in the developing world. In 2008, abortion rates in the 25 countries with complete records - all of which were developed - ranged from seven (Germany and Switzerland) to 30 (Estonia) per 1,000 women aged 15-44. Abortion rates declined in the majority of the 20 countries with consistently reliable information on trends between 1996 and 2008; declines were generally steeper than increases, although the pace of decline slowed after 2003. The highest observed abortion rates were in developing countries with incomplete estimates. For most developing countries that had liberal laws, the reported abortion rates were incomplete and varied widely.

CONCLUSIONS: High abortion rates in some countries, and small increases in rates in others, indicate a great need for more effective family planning services for these populations. Reliable data collection systems, needed to ensure that trends can be effectively monitored, are lacking in many countries.

International Perspectives on Sexual and Reproductive Health, 2011,37(2):84-94, doi:10.1363/3708411

The incidence of induced abortion is an important indicator of the frequency with which women experience unintended pregnancies, and it can point to gaps in contraceptive services and effective contraceptive use. Periodic assessments of abortion incidence are therefore essential for monitoring trends in these critical aspects of the wellbeing of women and couples.

However, documentation of this incidence is often unavailable or incomplete, in part because of the sensitive nature of abortion. Although it is extremely difficult to obtain reliable counts of the numbers of procedures performed in countries that have highly restrictive abortion laws, abortion data collection systems or other means of abortion estimation are in place in most countries that have liberal laws.

This review presents the most recent available official statistics and national estimates of the level of abortion in all countries and major territories where legal abortion was generally available in 2008-settings where abortion was legal without restriction as to reason or on socioeconomic grounds; or where abortion was legal to preserve a woman's physical or mental health, if the law was interpreted liberally. A recent analysis estimated that about $60 \%$ of women of childbearing age live in countries with liberal abortion laws. ${ }^{1}$ Another $3 \%$ live in countries whose abortion laws are interpreted liberally such that legal abortion is generally available.

The quality of abortion statistics varies greatly, and the completeness of the statistics depends on such factors as whether abortion reporting is voluntary or required by law; whether medication abortions are reliably reported; whether clinicians face consequences for failure to report abortions, such as lack of reimbursement for services rendered; whether reporting systems include services provided in the private sector (and, if not, the proportion of abortions performed in the private sector); and whether abortion stigma negatively influences reporting. The completeness of reporting can change over time if circumstances that influence reporting change.

In our analyses, we assess the completeness of abortion reports and whether the quality of reporting has changed substantially over time. Where completeness and availability of data permit, we compare current abortion levels with those observed in 1996 and 2003, the years covered in the most recent global reviews of legal abortion. 2,3

Since 1996, liberal abortion laws have gone into effect in Cambodia, Nepal, Portugal, South Africa, and Mexico's Federal District (Mexico City). ${ }^{4}$ In addition, the criteria for legal abortion were broadened in Ethiopia, where a substantial proportion of abortions are now legal. ${ }^{4}$ In all of 
these countries and territories except Portugal, however, large proportions of abortions still occur outside of approved facilities, and many of these procedures are likely unsafe. Although the abortion law was liberalized in India in 1971, large numbers of abortions are performed outside of facilities certified to provide legal abortions. ${ }^{5}$ For these countries, we present the official, reported abortion rates or estimates of incidence in approved facilities, as well as estimates of the overall incidence of abortion in the country (if available).

\section{METHODS}

\section{Data Collection}

For all countries and major territories that had liberal abortion laws in 2008, we sought statistics on legal induced abortions for the most recent year available after 2003.* We considered countries and territories to have liberal abortion laws if abortion was legal without restriction as to reason or was legal on socioeconomic grounds, either with or without gestational limits. In 2008, 71 countries and major territories fell in this category. ${ }^{4}$ We also sought information for countries whose laws allow for abortion to preserve the physical or mental health of the woman, if these laws are interpreted liberally (such that a substantial proportion of all abortions were deemed legal in 2008). To the best of our knowledge, Ethiopia, Hong Kong, Israel, New Zealand, South Korea and Spain ${ }^{\dagger}$ meet these criteria. ${ }^{\ddagger}$

We employed data collection methods similar to those used in previous reviews of legal abortion incidence worldwide. ${ }^{2,3}$ We started by searching Web sites of statistical offices or relevant government agencies for official abortion data. If such data could not be found online, we contacted these agencies directly and asked representatives to complete a standardized questionnaire on abortion incidence. Representatives were asked to provide the number of legally induced abortions that took place each year from 2003 to 2008, data on the characteristics of women who had induced abortions in 2008 and information on the types of procedures performed in 2008. If we did not receive a response to this request, we followed up with a more limited request for the official number of induced abortions in 2008. If this inquiry did not yield a response, we attempted to identify and solicit other informants who would have access to this information, primarily through Web searches and with the help of local contacts. For those few countries for which we could not obtain information from the above sources, we present abortion statistics from secondary sources, namely the United Nations' Demographic Yearbook ${ }^{6}$ and the World Health Organization's European health for all database. ${ }^{7}$ Although we could not verify the accuracy of these data, the statistics from these sources matched those from primary sources in the numerous cases where both were available. For the United States, we used findings from a census of abortion providers conducted by a nongovernmental organization, as these data are more complete than government reports. ${ }^{8}$

We compared reports of abortions for 2003 obtained during the current review with the numbers obtained during the prior review to ensure that these figures had not changed, and that the sources of information for the two reviews were comparable. Abortions performed in one country for residents of another country were included in the count for women's country of residence, when this number was known and exceeded 100.

We asked representatives of reporting agencies who provided data to comment on the completeness of the abortion reports. If the completeness of reports was in question, we also sought assessments from additional experts, including demographers and other social scientists, national and regional specialists in sexual and reproductive health, policy advisors and providers familiar with abortion reporting procedures in the country. All of this information was used to classify countries according to whether their abortion data were complete (defined as including at least $90 \%$ of all legal abortions), likely to be incomplete or of unknown completeness.

For a few countries whose official statistics were unavailable or deemed incomplete, we present abortion estimates from nationally representative surveys. We assumed that survey-based estimates were incomplete, because underreporting of abortion is often high, particularly in faceto-face interviews. The level of underreporting in such surveys has ranged from $15 \%$ to $69 \%$ in countries with liberal abortion laws, according to studies that have attempted to validate findings. ${ }^{9}$ Although neither surveys nor statistics provide complete figures for these countries, comparison between the two can aid in better understanding the quality of the two information sources.

Information for countries with recently liberalized abortion laws, as well as for India (where many unsafe abortions still occur), is presented separately. Figures for Ethiopia $\S$ and Mexico City are taken from studies that employed indirect estimation techniques, and thus they approximate abortion incidence in these settings. ${ }^{10}$

Of the 77 countries and territories eligible for this review, 41 are developed and 36 developing. We obtained data for 64.** Ninety-eight percent of women aged 15-44 who live in eligible countries reside in these 64 countries. For 25 of these countries, published or local sources indicated that

*In most cases, this was 2008. Exceptions are specified in the tables.

tThe law in Spain was further liberalized in 2010 to allow abortion on request up to 14 weeks' gestation.

₹The 2003 assessment included information on legal abortions obtained by women from Ireland and Northern Ireland, and legal menstrual regulations performed in Bangladesh, even though abortion laws are restrictive in these areas. Information for Ireland and Northern Ireland is presented in the text of this article. Updated information is not available for Bangladesh. None of the three are counted among the settings where legal abortion is widely available, as defined in this review.

$\S$ The number of legal abortions in Ethiopia was estimated directly from a prospective, facility-based study; the number of illegal abortions was estimated using indirect methods.

**Data were not available for Australia, Austria, Bahrain, Barbados, Belize, Bosnia and Herzegovina, Cape Verde, Cyprus, Fiji, Guyana, North Korea, Saint Vincent and the Grenadines, or Zambia. An estimate of abortion incidence in Australia in 2003 has been published, but a more recent formal estimate is not available. 
the statistics included at least $90 \%$ of the actual number of legal abortions performed in 2008.

For some countries, the classification of the completeness of their statistics has changed since 2003. Abortion statistics for Belarus, Canada, Cuba, Latvia, Lithuania, Russia and Tunisia were deemed complete in 2003 but incomplete in 2008. For Cuba, data on menstrual regulations, which accounted for more than half of all pregnancy terminations in 2003, were not available for 2008. The proportion of abortions in Russia that are privately performed and unreported is increasing, according to experts and published research. ${ }^{11}$ The official statistics on abortions in Spain were deemed possibly incomplete in 2003, but experts now indicate that these statistics have been consistently complete during the past decade. Canada and Tunisia have been reclassified because this review employed a more stringent definition of completeness than the last review (90\% vs. 80\%). For Latvia and Lithuania, at least one source believes that the quality of reporting has likely declined.

For countries with complete statistics for 2008 , we present estimates for 1996 and 2003 if they are available and are deemed to include at least $90 \%$ of all legal abortions. For some countries whose statistics fell within $10 \%$ of the estimated true number of abortions in all time periods, the level of coverage may nevertheless have changed over time. We note where such changes in coverage may have occurred. The level of completeness also may have changed since the 2003 review for countries with incomplete estimates; findings for 2003 are not presented here for those countries.

To calculate the abortion rate and the proportion of all pregnancies that ended in abortions in 2008 for each country, we obtained estimates of the population of women aged 15-44 and the number of live births. When available, we obtained these data from the United Nations Statistical Division, which compiles information from official statistical authorities. ${ }^{6}$ If population or birth data were unavailable from this source, we used estimates published in 2008 by the United Nations Population Division. ${ }^{12}$ We interpolated where necessary to obtain midyear population estimates for the year corresponding to the abortion statistics.

To calculate the number of pregnancies in 2008, we summed births, abortions and miscarriages. * We estimated the number of miscarriages in each country to be the sum of $20 \%$ of the number of births and $10 \%$ of the number of induced abortions, ${ }^{13}$ a formula supported by findings from a survey of women in the United States. ${ }^{14}$ This approach was used for all countries, as empirical data on the incidence of miscarriage do not exist for most countries.

*In this article, miscarriage refers to all spontaneous fetal losses that occur at least four weeks after the last menstrual period, as well as stillbirths.

tWe estimate the average lifetime number of abortions per woman by dividing the annual abortion rate by 1,000 (to compute the average number of abortions per woman per year) and multiplying the result by 30 (the number of years of her reproductive life).

\section{Analysis}

We calculated the abortion rate (the number of abortions annually per 1,000 women aged 15-44) for each of the countries covered, as well as the proportion of all pregnancies that end in abortion for the countries with complete abortion statistics. For estimates derived from surveys of women, we calculated the number of abortions from the reported abortion rates.

If complete and comparable abortion statistics were available for the relevant time periods, we present the compounded annual percentage change in the abortion rate between 1996 and 2003 and between 2003 and 2008. In some cases, statistics are for years close to 1996, 2003 and 2008; in all cases, annual rates of change are calculated using the exact years for which data were available for a country.

\section{RESULTS}

\section{Countries with Complete Statistics}

- Overall levels and trends. Among countries with relatively complete abortion reports, the United States had the most legal abortions in 2008-1.2 million (Table 1). The highest legal abortion rate was in Estonia (30 abortions per 1,000 women of reproductive age); at this rate, 100 Estonian women can expect to have a total of 90 abortions over their reproductive lifetimes, or 0.9 per woman. ${ }^{\dagger}$ However, higher numbers and rates were observed in some countries with incomplete counts or estimates. The lowest legal abortion rates were in Germany and Switzerland (seven per 1,000) and the Netherlands (eight per 1,000). At these rates, 100 women can expect to have 20-25 abortions during their lifetimes.

The proportion of pregnancies that ended in induced abortion was lowest in Israel (10\%), followed closely by the Netherlands and Switzerland (11\% each); the highest was in Estonia (30\%). The abortion rate declined between 1996 and 2008 in 11 of the 20 countries with complete statistics (Table 1 and Web Appendix Figure 1). The rate fell most precipitously in the countries that had the highest incidence of abortion in 1996. In most of the countries where the abortion rate declined, the pace of the decrease slowed after 2003. In the remaining countries with complete statistics, the rate rose between 1996 and 2008, but all of the increases were small (1-3 abortions per 1,000 women). The greatest cumulative decline was in Bulgaria, where the rate fell by $69 \%$; the greatest increase was in New Zealand, where the rate rose by 16\% (not shown).

Between 2003 and 2008, the abortion rate declined by more than one point in six of the 24 countries with complete data, rose by more than one point in three and remained relatively stable in 15 . The sharpest decline occurred in Bulgaria, where the abortion rate fell by $6 \%$ per year on average, and the steepest annual rise was in Spain, where the rate rose by $7 \%$ per year. The increase in the overall rate in Spain has been attributed to the rapidly growing immigrant population; experts indicated that the rate in the nonimmigrant population has probably been 


\begin{tabular}{|c|c|c|c|c|c|c|c|c|c|}
\hline \multirow[t]{2}{*}{ Country } & \multicolumn{3}{|l|}{ No. } & \multicolumn{3}{|l|}{ Rate } & \multicolumn{2}{|c|}{$\begin{array}{l}\text { Annual \% change } \\
\text { in rate }\end{array}$} & \multirow{2}{*}{$\begin{array}{l}\text { \% of pregnancies } \\
\text { ending in abortion }\end{array}$} \\
\hline & 2008 & 2003 & 1996 & 2008 & 2003 & 1996 & $\begin{array}{l}2003- \\
2008\end{array}$ & $\begin{array}{l}1996- \\
2003\end{array}$ & \\
\hline \multicolumn{10}{|l|}{ EUROPE } \\
\hline Bulgaria & 24,900 & 34,700 & 89,000 & 16 & 22 & 51 & -5.8 & -11.7 & 21 \\
\hline Czech Republic* & 25,800 & 29,300 & 46,500 & 12 & 14 & 21 & -3.0 & -6.9 & 16 \\
\hline Hungary & 44,100 & 53,800 & 76,600 & 21 & 26 & 35 & -3.8 & -4.2 & 26 \\
\hline Slovakia & 13,400 & 16,200 & 25,200 & 11 & 13 & 20 & -3.6 & -6.1 & 16 \\
\hline \multicolumn{10}{|c|}{ Northern/Southern/Western } \\
\hline Belgium & 19,300 & 16,200 & 14,800 & 9 & 7 & 7 & 4.2 & 1.7 & 12 \\
\hline Denmark† & 16,200 & 15,600 & 18,100 & 15 & 15 & 16 & 0.6 & -1.6 & 18 \\
\hline England and Walest & 189,800 & 181,600 & 167,900 & 17 & 17 & 16 & 0.4 & 0.9 & 18 \\
\hline Estonia & 8,400 & 10,600 & 16,900 & 30 & 36 & 56 & -3.8 & -6.1 & 30 \\
\hline Finland & 10,400 & 10,700 & 10,400 & 11 & 11 & 10 & -0.4 & 1.1 & 13 \\
\hline France & 198,200 & 208,800 & 189,800 & 16 & 17 & 15 & -0.1 & 1.6 & 18 \\
\hline Germany† & 110,700 & 129,300 & 130,900 & 7 & 8 & 8 & -1.3 & 0.2 & 12 \\
\hline Iceland & 1,000 & 1,000 & 800 & 14 & 15 & $\mathrm{u}$ & -1.1 & $\mathrm{u}$ & 14 \\
\hline Italy*,†,キ & 117,100 & 132,200 & $\mathrm{u}$ & 10 & 11 & $\mathrm{u}$ & -1.4 & $\mathrm{u}$ & 15 \\
\hline Netherlands & 27,600 & 28,800 & 22,400 & 8 & 9 & 7 & -0.2 & 4.0 & 11 \\
\hline Norway & 16,100 & 13,800 & 14,300 & 17 & 15 & 16 & 2.3 & -0.5 & 19 \\
\hline Portugalt & 19,600 & $\mathrm{u}$ & $\mathrm{u}$ & 9 & $\mathrm{u}$ & $\mathrm{u}$ & $\mathrm{u}$ & $\mathrm{u}$ & 14 \\
\hline Scotland & 14,100 & 12,600 & 12,300 & 13 & 12 & 11 & 3.0 & 0.5 & 16 \\
\hline Slovenia & 4,900 & 6,900 & 10,400 & 12 & 16 & 23 & -5.5 & -5.2 & 17 \\
\hline Spain & 115,800 & 79,800 & $\mathrm{u}$ & 12 & 8 & u & 7.1 & $\mathrm{u}$ & 16 \\
\hline Swedent & 37,500 & 34,400 & 32,100 & 21 & 20 & 19 & 0.6 & 1.1 & 22 \\
\hline Switzerland & 10,800 & 10,500 & $\mathrm{u}$ & 7 & 7 & u & -0.3 & $\mathrm{u}$ & 11 \\
\hline \multicolumn{10}{|l|}{ NORTH AMERICA } \\
\hline United States* & $1,213,000$ & $1,250,000$ & $1,360,200$ & 20 & 21 & 22 & -1.2 & -1.2 & 19 \\
\hline \multicolumn{10}{|l|}{ OCEANIA } \\
\hline New Zealand & 17,900 & 18,500 & 14,800 & 20 & 21 & 17 & -1.2 & 2.8 & 20 \\
\hline \multicolumn{10}{|l|}{ ASIA } \\
\hline Israel & 19,600 & 20,800 & 17,400 & 13 & 14 & 14 & -1.8 & 0.6 & 10 \\
\hline Singapore & 12,200 & 12,300 & 14,400 & 14 & 15 & 16 & -0.6 & -0.9 & 21 \\
\hline
\end{tabular}

*Abortion counts and rates for 2003 have been updated since prior review. †Most recent estimates are for 2009. $¥$ The quality of reporting likely improved between 2003 and 2008. Notes: Numbers of abortions are rounded to the nearest 100 . Rates are numbers of abortions per 1,000 women aged 15-44.Pregnancies comprise live births, abortions and miscarriages. $u=$ unavailable.

fairly steady, and that in 2008, the abortion rate among foreign-born women was triple that of native-born women. Some $45 \%$ of abortions were provided to women born outside of Spain (most frequently in South America), even though separate statistics indicate that only $11 \%$ of women in Spain are foreign-born. ${ }^{15}$

-Eastern Europe. The decline in abortion incidence observed in Eastern Europe between 1996 and 2003 continued in ensuing years, but at a markedly slower pace. The annual declines in the rate were still high relative to those in other countries, and ranged from 3\% in the Czech Republic to $6 \%$ in Bulgaria. In 2008, abortion rates ranged from 11 per 1,000 in Slovakia to 21 per 1,000 in Hungary. The proportion of pregnancies ending in abortion was greatest in Hungary (26\%).

- Northern, Southern and Western Europe. Abortion rates also continued to decline fairly rapidly between 2003 and 2008 (by 4-6\% annually) in the former Soviet countries outside of Eastern Europe-Estonia and Slovenia. In contrast, rates held fairly steady in Denmark, England and Wales, Finland, France, Germany, the Netherlands and Switzerland, where they ranged from seven to 17 per 1,000 women of reproductive age in 2008. The abortion rate rose slightly but consistently across the two intervals in Scotland (from 11 to 13) and Sweden (from 19 to 21). It also increased in Norway (from 15 to 17) after 2003. The abortion rate appears to have declined slightly in Italy between 2003 and 2008 (from 11 to 10), despite some improvement in the quality of reporting.

Although abortion laws are restrictive in Ireland and Northern Ireland, residents of these areas obtain abortions in England and Wales at rates of at least five and four abortions per 1,000 women, respectively (not shown). Data are lacking on abortions obtained by Irish women who provided non-Irish addresses when obtaining abortions in England and Wales, who obtained abortions in other countries or who had abortions in Ireland and Northern Ireland, so such abortions are excluded from these counts.

In France, the abortion rate was 16 per 1,000 women in 2008. The country's official report also provides statistics on procedures carried out in several small French territories and departments abroad (not shown), all of which have higher abortion rates than France itself-French Guyana (38), Guadeloupe (45), Martinique (28) and the 


\begin{tabular}{|c|c|c|c|}
\hline Country & No. & Rate & Year \\
\hline \multicolumn{4}{|l|}{$\begin{array}{l}\text { EUROPE } \\
\text { Eastern }\end{array}$} \\
\hline Belarus & 46,300 & 19 & 2008 \\
\hline Moldova & 12,300 & 14 & 2008 \\
\hline Romania & 77,000 & 16 & 2008 \\
\hline Russian Federation & $1,208,700$ & 38 & 2008 \\
\hline Ukraine & 127,500 & 12 & 2008 \\
\hline Ukraine* & 151,500 & 15 & 2007 \\
\hline \multicolumn{4}{|l|}{ Southern } \\
\hline Albania & 3,900 & 5 & 2008 \\
\hline Albania* & 4,100 & 6 & 2009 \\
\hline Croatia & 4,500 & 5 & 2008 \\
\hline Greece & 16,500 & 7 & 2005 \\
\hline Macedonia† & 5,700 & 12 & 2008 \\
\hline Montenegro & 1,100 & 8 & 2008 \\
\hline Serbia & 22,700 & 16 & 2008 \\
\hline \multicolumn{4}{|l|}{ Northern } \\
\hline Latvia & 10,400 & 20 & 2008 \\
\hline Lithuania & 9,000 & 12 & 2008 \\
\hline \multicolumn{4}{|l|}{ NORTH AMERICA } \\
\hline Canada & 94,000 & 14 & 2008 \\
\hline \multicolumn{4}{|l|}{ ASIA } \\
\hline \multicolumn{4}{|l|}{ Central } \\
\hline Kazakhstan & 124,000 & 32 & 2008 \\
\hline Kyrgyzstant & 20,800 & 16 & 2008 \\
\hline Tajikistant & 18,500 & 11 & 2008 \\
\hline Turkmenistan & 12,200 & 9 & 2008 \\
\hline Uzbekistant & 40,000 & 5 & 2008 \\
\hline \multicolumn{4}{|l|}{ Eastern } \\
\hline China & $9,173,100$ & 29 & 2008 \\
\hline Hong Kong & 13,200 & 8 & 2008 \\
\hline Japan $\neq$ & 242,300 & 10 & 2008 \\
\hline Mongolia & 10,700 & 15 & 2008 \\
\hline South Korea* & 124,700 & 11 & 2006 \\
\hline Taiwan* & 78,800 & 17 & 2007 \\
\hline \multicolumn{4}{|l|}{ Southeast } \\
\hline Vietnam & 332,200 & 15 & 2008 \\
\hline \multicolumn{4}{|l|}{ Western } \\
\hline Armenia & 9,000 & 12 & 2008 \\
\hline Armenia & 40,600 & 54 & 2005 \\
\hline Azerbaijan & 10,400 & 7 & 2008 \\
\hline Azerbaijan* & 159,700 & 81 & 2006 \\
\hline Georgia & 19,100 & 19 & 2008 \\
\hline Turkey* & 177,100 & 10 & 2008 \\
\hline \multicolumn{4}{|c|}{ LATIN AMERICA/CARIBBEAN } \\
\hline Cuba§ & 74,800 & 29 & 2008 \\
\hline Puerto Rico** & 6,900 & 7 & 2006 \\
\hline \multicolumn{4}{|l|}{ AFRICA } \\
\hline Tunisia & 14,700 & 6 & 2009 \\
\hline
\end{tabular}

*Estimates are based on data from a nationally representative survey of women aged 15-44, except in South Korea (married women aged 20-44) and Turkey (ever-married women aged 15-44). Estimates reflect the average for the three years preceding the survey, except in Taiwan (preceding year) and in South Korea and Turkey (preceding five years). Number of abortions was calculated from the abortion rate, except in Turkey (calculated from total abortion rate). Numbers and rates may include a small number of illegal abortions. Estimate may include spontaneous abortions. ‡Data are for April 2008-March 2009. $\S$ Data do not include menstrual regulations. **Data are for July 2005-June 2006. Notes: Numbers of abortions are rounded to the nearest 100 . Rates are numbers of abortions per 1,000 women aged 15-44. Unless otherwise noted all figures are based on data from official country reports, the United Nations Demographic Yearbook or the World Health Organization's European health for all database.
Réunion Islands (20)

Spain was not the only European country for which official reports and published studies indicate large differentials in abortion rates by women's country of origin. In Italy, although only $6 \%$ of women were foreign-born residents in 2008, ${ }^{12}$ more than $30 \%$ of abortions in 2008 were provided to foreign-born women, ${ }^{16}$ a proportion that has increased over time. ${ }^{17}$ Recent studies also indicate that $25-36 \%$ of abortions in Finland, ${ }^{18}$ the Netherlands, ${ }^{19}$ Norway $^{20}$ and Sweden ${ }^{21,22}$ have been provided to foreign-born women, largely those of non-European origin. Only 4\% and $8 \%$ of women in Finland ${ }^{23}$ and Norway, ${ }^{24}$ respectively, were foreign-born residents in 2008, and 17\% and 26\% of women in Sweden ${ }^{25}$ and the Netherlands ${ }^{26}$ were foreign-born residents.

- North America and Oceania. The abortion rate in both the United States and New Zealand was 20 per 1,000 reproductive-aged women in 2008. In the United States, incidence declined between 1996 and 2008. The abortion rate also declined slightly in New Zealand, after an increase between 1996 and 2003. In both countries, $19-20 \%$ of pregnancies ended in induced abortion in 2008. An official estimate of the number of abortions in Australia is unavailable, but findings from an assessment that used insurance claims and hospital statistics and employed the same approach used to estimate abortions in 2003 indicate that the rate may have decreased slightly, from 19 to $18 .^{27,28}$ Complete statistics are available for South Australia, where the rate declined slightly, from 17 in 2003 to 16 in 2008 (not shown). ${ }^{29}$

-Asia. The only Asian countries with liberal abortion laws and complete statistics were Israel and Singapore. Abortion incidence decreased slightly in both countries between 2003 and 2008, to rates of 13 and 14 per 1,000 women, respectively (Table 1 )

\section{Countries with Incomplete Statistics}

The numbers and rates for most of the 33 countries whose statistics were incomplete or of unknown completeness are minimum figures. Because the completeness of reports may have changed over time, caution is warranted when comparing these estimates to earlier figures published previously; ${ }^{3}$ however, we comment on possible trends where feasible.

- Eastern Europe. The reported abortion rates for Eastern European countries with incomplete reporting for 2008 ranged from 12 in Ukraine to 38 in Russia (Table 2). For all countries but Moldova, reported rates were much lower in 2008 than in 2003, when they ranged from 22 in Ukraine to 45 in Russia (not shown). However, experts indicated that the number of unreported, privately performed abortions in this region has increased substantially, though the levels of such abortions are unknown. Informants believed that the declines in the official numbers represent a combination of real declines in incidence and a shift to unreported abortions.

- Southern Europe. The reported abortion rates for coun- 
tries with incomplete reporting in Southern Europe ranged from five (Albania and Croatia) to 16 (Serbia) in 2008. Informants indicated that actual abortion rates were several times higher than reported levels in at least some of the listed countries. Fertility rates were below replacement level in these countries, ${ }^{30}$ yet the prevalence of modern contraceptive use was low (46\% in Greece and less than $23 \%$ in all other countries), ${ }^{31}$ suggesting that reliance on abortion to prevent unwanted births remained moderate to high. Moreover, the most commonly used modern method was the condom, which can have a high failure rate.

- Northern Europe. Abortion statistics for 2003 were believed to be reasonably complete for Latvia and Lithuania, but official records for 2008 are thought to be incomplete. Experts indicated, however, that the incidence of abortion appears to have declined (not shown).

- North America. According to official reports, the abortion rate in Canada declined from 15 to 14 per 1,000 reproductive-age women between 2003 and 2008. However, a growing proportion of all abortions in Canada are performed in clinics, which are not required to report abortions. $^{32,33}$ It is therefore possible that the completeness of official counts decreased slightly after 2003, and that the decline in reported incidence is spurious or overstated.

- Central Asia. Except for Kazakhstan, the reported abortion rates in Central Asia were low in 2008, ranging from five to 16 per 1,000. At the time of the prior review, surveybased estimates were available for Kazakhstan, Kyrgyzstan and Uzbekistan, and official counts were as little as onesixth of the survey-based estimates. Information on whether the quality of official statistics has changed since 2003 is not available.

- Eastern Asia. China's Ministry of Health reports that more than 9.1 million abortions were performed in the country in 2008; the rate of 29 abortions per 1,000 women represents a $27 \%$ increase since 2003. However, official statistics have fluctuated widely from year to year, suggesting that the quality of reporting is inconsistent. Thus, whether the difference between the 2003 and 2008 reports reflects a real or spurious trend is unclear. Experts have suggested that abortion levels might be increasing in China, because sexual activity among unmarried women is becoming more common, yet stigma prevents many of these women from seeking contraceptives. ${ }^{34,35}$ Some increase in abortions may also result from the barriers to obtaining contraceptive services faced by the rapidly growing urban migrant population, which increased from 100 million in 2000 to 230 million in 2009. 36

The official abortion figure for 2008, which is higher than the figures for the adjacent years, might be inflated because of tabulation errors. Alternatively, it could be incomplete if women obtained unreported private-sector abortions. The experience of other countries suggests that economic growth could prompt an increase in use of the private sector for health care among individuals seeking better quality services; informants provided mixed opin- ions as to whether this has been the case in China. Sexselective abortions continue to occur in China, ${ }^{35}$ and some of these might be obtained outside the public sector and may not have been reported. In addition, women may be ending pregnancies with mifepristone obtained from sources other than hospitals and clinics.

Findings from a 2006 survey of married women aged 20-44 in South Korea indicate that 124,700 abortions occurred that year; when applied to the population of women (both married and unmarried) aged 15-44, this figure translates to an annual rate of 11 per 1,000 women. Experts suggested that the true number and rate were much higher, both because women tend to underreport abortions and because many abortions are obtained by unmarried women, who were not interviewed in the survey. Moreover, the experts noted that premarital sex, which is increasingly prevalent in South Korea, ${ }^{37}$ could be playing a growing role in abortion incidence.

Survey-based estimates suggest that the abortion rate in Taiwan declined from 23 to 17 per 1,000 between 2003 and 2007; this decrease appears to be a result of increased contraceptive use. ${ }^{38}$

- Southeast Asia. In Vietnam, abortion services have increasingly been provided outside of the public sector since the mid-1990s, rendering the official counts of abortions less and less complete. ${ }^{39,40}$ Official counts indicate that the abortion rate fell from 83 to 15 abortions per 1,000 women between 1996 and 2008. In contrast, surveys of women in 1996 and 2002 suggest that abortion levels held steady during that interval (though underreporting in the surveys was substantial); survey-based estimates of trends in contraceptive use and fertility were consistent with a steady abortion rate. ${ }^{41}$ More recent survey data are not available.

-Western Asia. At the time of the prior review, surveys revealed that women in Armenia, Azerbaijan and Georgia had the highest legal abortion rates in the world. Since then, surveys have found that abortion rates in Armenia and Azerbaijan remain the highest reported (54 and 81, respectively), though they are lower than rates reported in previous surveys (81 and 116). The apparent declines in abortion rates indicated by the surveys are not borne out by changes in contraceptive use and fertility, ${ }^{42,43}$ which has led to suggestions that the relatively low estimates from recent surveys reflect that abortion is increasingly stigmatized (resulting in greater reluctance on the part of women to report abortions in surveys) and that use of misoprostol (either as an abortifacient or to regulate menstruation without a pregnancy test) may have risen and may be underreported in surveys. ${ }^{42,43}$ No survey estimates for Georgia have become available since the last review, which reported an estimate of 103 abortions per 1,000 women for 2005.

- Latin America and the Caribbean. Official statistics indicate that the abortion rate in Cuba was 29 per 1,000 women in 2008, but these data exclude menstrual regulations (most of which are pregnancy terminations), which 


\begin{tabular}{|c|c|c|c|c|c|c|}
\hline \multirow[t]{2}{*}{ Country } & \multicolumn{2}{|l|}{ No. } & \multicolumn{2}{|l|}{ Rate } & \multirow[t]{2}{*}{ Year } & \multirow[t]{2}{*}{ Source } \\
\hline & Legal & All & Legal & All & & \\
\hline \multicolumn{7}{|c|}{ LATIN AMERICA/CARIBBEAN } \\
\hline Mexico City* & 13,400 & u & 6 & u & 2008 & Official record \\
\hline Mexico City & u & 165,500 & $\mathrm{u}$ & 34 & 2006 & Indirect estimation \\
\hline \multicolumn{7}{|l|}{ ASIA } \\
\hline Cambodia & 35,200 & 73,900 & 11 & 22 & 2005 & Indirect estimation \\
\hline India & 641,800 & u & 2 & u & 2008 & Official record \\
\hline Nepal† & 97,400 & u & 15 & $\mathrm{u}$ & 2008 & Official record \\
\hline \multicolumn{7}{|l|}{ AFRICA } \\
\hline Ethiopia & 103,000 & 382,500 & 6 & 23 & 2008 & Indirect estimation \\
\hline South Africa & 77,200 & u & 6 & u & 2009 & Official record \\
\hline
\end{tabular}

*Abortions in public medical facilities only. †Data are for July 2007-June 2008. Notes: All counts and rates are estimates. Numbers of abortions are rounded to the nearest 100 . Rates are numbers of abortions per 1,000 women aged 15-44.u=unavailable. accounted for $57 \%$ of procedures in $2004 .{ }^{44}$ According to Ministry of Health statistics, the abortion rate excluding menstrual regulations rose by 16\% between 2003 and 2008, after a long period of decline between the mid-1980s and the early 2000 s.

The official count of abortions in Puerto Rico in 2006 translates to a rate of seven abortions per 1,000 women. The official rate was also low in 2003 (nine per 1,000). Both estimates fall far short of the survey-based estimate of 18 per 1,000 in $2001,{ }^{45}$ indicating severe underreporting in the official record. A more recent survey-based estimate is not available.

-Africa. Tunisia is the only African country with incomplete abortion statistics and a liberal abortion law. Official reports indicate that the rate fell from 10 to six per 1,000 between 1996 and 2009; experts suggested that the lower rate in 2009 reflects a combination of a true decline, resulting from both increased contraceptive use and later age at marriage (along with continued low levels of premarital sexual activity), and a decline in the coverage of reports, resulting from growing numbers of privately performed abortions. Surveys indicate that a small increase in contraceptive prevalence occurred between 1994 and 2001, and a sharp increase in the age at marriage occurred from the mid-1970s to the early 2000s, ${ }^{46}$ but no information is available on whether these trends continued into the late 2000 s.

\section{Countries with Legal and Illegal Abortions}

In some countries, as well as Mexico City, many unsafe abortions occur despite liberal abortion laws. Abortion counts and estimates for some of these jurisdictions are available from various sources. In jurisdictions with official reporting systems, large numbers of unreported abortions-some of which are unsafe, illegal or both-still occur, for several reasons: the reporting systems may not be sufficiently developed; the number of approved providers may be insufficient to satisfy the demand; regulations regarding eligibility to provide legally sanctioned abortions may be onerous; and unreported private abortions may be lower in cost or easier to obtain, or may seem to confer more privacy than public-sector procedures. Cambodia and Ethiopia lack official reporting systems, but evidence indicates that both safe and unsafe abortions occur. Estimates of overall abortion incidence are available for only three of these six countries and territories (Table 3).

Mexico City's abortion law was liberalized in 2007, and several public hospitals, a few public-sector clinics, and private physicians now provide legal abortion services. The official report indicates that 13,400 abortions were performed in public facilities in 2008, which translates to a rate of approximately six per 1,000 residents of Mexico City. By contrast, according to a national study, 165,500 abortions were performed in Mexico City in 2006, and the abortion rate was 34.47 If this rate held steady after the change in the law, then only $8 \%$ of all abortions in that region were provided in the public sector.

According to a survey of health facilities in Cambodia, 35,200 abortions took place in public and private facilities staffed by trained providers in 2005. These findings, together with information from surveys of women on the percentage distribution of abortions according to where they were performed, suggest that an additional 38,700 abortions occurred in women's homes and other locations, for an overall abortion rate of 22 per 1,000 reproductive-aged women. ${ }^{48}$

Although the official report from India indicates that only two legal abortions per 1,000 women were performed in 2008 (down from three in 2003), a facility-based survey in 2002 estimated an overall rate of 26 abortions per 1,000 women, of which more than one-third were considered safe, even if they did not conform with all of the regulatory conditions imposed by law. Mifepristone and misoprostol manufacturing and sales data ${ }^{49}$ suggest that the use of medication abortion has increased substantially in recent years. However, the extent to which this increase reflects a shift from surgical abortion, and the degree to which it represents a rise in overall abortion levels, are unclear.

A liberal abortion law went into effect in 2004 in Nepal. The number of service sites and trained providers has increased rapidly across the country, and the recorded rate of legal abortions increased from five to 15 per 1,000 between 2005 and 2008. ${ }^{50}$ Nevertheless, it is possible that large numbers of unreported abortions occur; a knowledgeable informant indicated that the number of abortions performed by unregistered providers in 2008 was likely equal to those done by registered providers.

As of 2005, abortion is allowed in Ethiopia under a range of conditions; the most liberal of these are when continuation of the pregnancy endangers the health of the woman or the fetus, and when the woman is unable to bring up the child owing to her status as a minor or to a physical or mental infirmity. According to a nationally representative survey of public and private facilities, 103,000 legal abortions were performed in such facilities nation- 
wide in 2008, representing an annual rate of six per 1,000 women. ${ }^{51}$ Indirect estimates of the total abortion incidence, developed as part of the same study, indicate that legal abortions accounted for $27 \%$ of all abortions performed, which leads to an estimated overall rate of 23 per 1,000 women.

A law allowing abortion on request during the first trimester was enacted in South Africa in 1997. Official statistics indicate that between 2003 and 2008, the annual rate remained steady at six per 1,000 women. However, sources reported that official data on legal abortions are incomplete because private-sector providers often fail to report some abortions, particularly medication abortions, and a few provinces delay or omit reporting for technical reasons. An unknown number of women resort to privatesector abortions, as the demand for services exceeds the capacity of public facilities, partly because some providers remain reluctant to perform abortions. ${ }^{52}$ An estimate of the rate of illegal abortion is not available, but South Africa accounts for $90 \%$ of the population in Southern Africa, and the estimated rate of unsafe (largely illegal) abortions in this region was nine per 1,000 in $2008 .^{53}$

\section{DISCUSSION}

Among the countries with reliable information on abortion trends between 1996 and 2008, more have experienced decreases than increases in their rates. Moreover, the declines in abortion rates tended to be steeper than the increases. In 2008, the highest rates of legal abortion were in Azerbaijan and Armenia, and the lowest were in Germany, Switzerland and the Netherlands.

Of the 77 countries and territories in which legal abortion is generally available, 41 are in the developed world. Abortion rates ranged from seven to 30 per 1,000 women aged 15-44 in developed countries with complete statistics in 2008. Abortion information was incomplete for most developing countries, and reported rates in these countries varied widely.

Abortion rates continued to decline in the former Soviet countries after 2003, as they had between 1996 and 2003, and the changes in incidence continue to be more dramatic there than in any other region of the world. Abortion levels in these countries, once uniformly high, varied widely in 2008, and rates in several of them were comparable with those of other developed countries. However, estimates for others, including Russia, Armenia and Azerbaijan, remained high. Overall, the pace of decline in this region appears to have greatly slowed, and if abortion rates plateau at or near current levels, some of the countries in this region will continue to have the highest rates of legal abortion in the world.

After declining between 1996 and 2003, abortion incidence appears to have risen in China, although the evidence for the recent increase is tenuous. If the rate has increased, the most likely explanations, namely increased premarital sexual activity and internal migration, could come into play in other countries during periods of rapid economic growth. An increase in the prevalence of premarital sexual activity has also been singled out as an important reason for rising abortion rates among young women in Japan. ${ }^{54}$ Surveys and other studies from South Korea $^{37}$ and Vietnam ${ }^{41}$ suggest that premarital sexual activity is also on the rise in these countries.

In many European countries outside of the former Soviet bloc, the size of the immigrant population has been increasing, ${ }^{12}$ and in many of these countries immigrants have abortions at higher rates than nonimmigrants. Similarly, in the United States, 16\% of abortions in 2008 were provided to foreign-born women, ${ }^{55}$ who account for $11 \%$ of the female population. ${ }^{56}$ National statistics likely mask important subnational disparities in abortion levels in other respects as well; abortion rates differ substantially by women's social and demographic characteristics in the United States, ${ }^{55}$ and differentials by ethnicity have been observed in the United Kingdom. ${ }^{57}$ Women who belong to subgroups with high abortion rates may have inadequate knowledge of contraception, difficulties accessing family planning services, weak social networks to support sustained contraceptive use, or values that conflict with contraceptive use. Information on disparities in abortion levels within countries is vital to identifying populations most at risk for unintended pregnancy and most in need of services to help them avoid such pregnancies.

An assessment of the quality of official abortion statistics, and of how their quality may have changed over time, is critical to helping stakeholders properly use these data. For nearly half of the countries in this review, the official records were deemed incomplete on the basis of the input of country experts or empirical evidence from other sources.

Private-sector abortions represent a growing proportion of abortions in many parts of the world, including Eastern Europe and parts of Asia. Because this sector is much more likely than the public sector to underreport abortions, this phenomenon is increasingly compromising researchers' ability to assess trends on the basis of official statistics. In addition, medication abortions are more likely than surgical abortions to be missed in official counts, especially where abortifacients can be obtained at nonpublic facilities, such as pharmacies. Other means of measuring abortions, such as nationally representative surveys of women or providers, which so far have largely been viewed as needed only in settings where abortions are largely clandestine, may become increasingly important as sources of information in countries with legal abortions.

The extent to which the declines in abortion rates in some countries reflect declines in unintended pregnancy or barriers to abortion services is unclear. In some of the former Soviet countries, significant fees have been imposed on services that once were free. ${ }^{58}$ In Russia, the grounds for legal abortion after the 12th week of gestation were narrowed in 2003; however, this seems to have had little impact on incidence, as the proportion of all abortions that occur beyond the 12 th week remained at $1-2 \%$ 
in 2008 .

Evidence indicates that the legal status of abortion has little influence on abortion levels, but is associated with the safety of the procedure. ${ }^{59}$ A number of countries have liberalized their abortion laws since the mid-1990s. More research is warranted on the impact of abortion law reform on women's reproductive health, and on the processes that need to follow legal reform to ensure a reduction in the incidence of unsafe abortion.

In many countries with liberal abortion laws, contraceptive prevalence is high and abortions are nevertheless taking place. The fact that abortions occur in measurable numbers in all of the countries reviewed here-including those where contraceptive prevalence is high-adds to the evidence that in all societies, some women and couples will have unintended pregnancies, and some of them will decide to end their pregnancies. Because all contraceptive methods, including sterilization, have failures, it is important to ensure access to safe abortion services.

However, research does consistently indicate that abortion is less common where contraceptive use is widespread. ${ }^{60,61}$ Whether safe or unsafe, abortions are generally more demanding of women and health care systems than contraception. Improving access to contraceptives for all women and couples and improving the effectiveness of use among those who are already using a method are crucial steps toward reducing the incidence of unintended pregnancy and induced abortion worldwide.

\section{REFERENCES}

1. Singh S et al., Abortion Worldwide: A Decade of Uneven Progress, New York: Guttmacher Institute, 2009

2. Henshaw SK, Singh S and Haas T, The incidence of abortion worldwide, International Family Planning Perspectives, 1999, 25(Suppl.): S30-S38.

3. Sedgh $G$ et al., Legal abortion worldwide: incidence and recent trends, International Family Planning Perspectives, 2007, 33(3):106-116.

4. Boland R and Katzive L, Developments in laws on induced abortion: 1998-2007, International Family Planning Perspectives, 2008, 34(3): $110-120$

5. Duggal R and Ramachandran V, Abortion Assessment Project-India: Summary and Key Findings, Mumbai: Center for Enquiry into Health and Allied Themes and Healthwatch, 2004

6. United Nations (UN), Demographic Yearbook 2008, New York: UN, 2010, Table 7, <http://unstats.un.org/unsd/demographic/products/ dyb/dyb2008/Table07.pdf >, accessed Feb. 8, 2011.

7. World Health Organization (WHO) Regional Office for Europe, European health for all database, no date, <http://data.euro.who.int/ hfadb/>, accessed Feb. 17, 2011.

8. Jones RK and Kooistra K, Abortion incidence and access to services in the United States, 2008, Perspectives on Sexual and Reproductive Health, 2011, 43(1):41-50.

9. Rossier C, Estimating induced abortion rates: a review, Studies in Family Planning, 2003, 34(2):87-102

10. Singh S, Prada E and Juarez F, The abortion incidence complications method: a quantitative technique, in: Singh S, Remez L and Tartaglione A, eds., Methodologies for Estimating Abortion Incidence and Abortion-Related Morbidity: A Review, New York: Guttmacher Institute; and Paris: International Union for the Scientific Study of Population (IUSSP), 2010, pp. 71-85.

11. Philipov D et al., Induced abortion in Russia: recent trends and un- derreporting in surveys, European Journal of Population, 2004, 20(2): 95-117.

12. Population Division, UN Department of Economic and Social Affairs, World population prospects: the 2008 revision, no date, <http://esa.un. org/unpp>, accessed Feb. 9, 2011.

13. Bongaarts J and Potter RE, Fertility, Biology, and Behavior: An Analysis of the Proximate Determinants, New York: Academic Press, 1983

14. Finer LB and Henshaw SK, Disparities in rates of unintended pregnancy in the United States, 1994 and 2001, Perspectives on Sexual and Reproductive Health, 2006, 38(2):90-96.

15. Instituto Nacional de Estadistica, Statistical Yearbook of Spain 2009 no date, <http://www.ine.es/prodyser/pubweb/anuario09/anu09_ 02demog.pdf>, accessed Apr. 6, 2011

16.Grandolfo M et al., Epidemiological surveillance system on induced abortion, Notiziaria dell' Istituto Superiore di Sanità, 2009, 22(5):1-7 (in Italian).

17. Italian National Institute of Statistics, I.Stat: data warehouse of the Institute, no date, <http://en.istat.it/dati/i_stat.html>, accessed Apr. 6 , 2011

18. Malin $M$ and Gissler M, Induced abortions among immigrant women in Finland, Finnish Journal of Ethnicity and Migration, 2008, $3(1): 2-12$

19. Rademakers J, Mouthaan I and de Neef M, Diversity in sexual health: problems and dilemmas, European Journal of Contraception $\&$ Reproductive Health Care, 2005, 10(4):207-211.

20. Eskild A et al., Induced abortion among women with foreign cul tural background in Oslo, Tidsskr Nor Laegeforen, 2002, 122(14) 1355-1357 (in Norwegian)

21. Helstrom L et al., Abortion rate and contraceptive practices in immigrant and native women in Sweden, Scandinavian Journal of Public Health, 2003, 31(6):405-410.

22. Helstrom L, Zatterstrom C and Odlind V, Abortion rate and contraceptive practices in immigrant and Swedish adolescents, Journal of Pediatric and Adolescent Gynecology, 2006, 19(3):209-213.

23. Statistics Finland, Nationality according to age and gender by re gion 1990-2010, no date, <http://pxweb2.stat.fi/database/StatFin/ vrm/vaerak/vaerak_en.asp>, accessed Apr. 6, 2011

24. Statistics Norway, Table 05196: Population, by sex, age and citizenship, no date, <http://statbank.ssb.nostatistikkbanken/Default_ FR.asp $?$ PXSid $=0 \&$ nvl $=$ true $\&$ PLanguage $=1 \&$ tilside $=$ selecttable $/$ hovedtabellHjem.asp\&KortnavnWeb=folkemengde>, accessed Apr. 6 , 2011

25. Statistics Sweden, Population size, number of deaths, immigrants, emigrants and average population size by country of birth, sex and age: year 2008-2110, no date, <http://www.ssd.scb.se/databaser makro/MainTable.asp?yp=tansss\&xu=C9233001\&omradekod=BE\&o mradetext=Population\&lang=2\&langdb=2>, accessed Apr. 6, 2011

26. Netherlands Centraal Bureau voor de Statistiek, Statline, no date, $<$ http://statline.cbs.nl/StatWeb/default.aspx?LA=EN>, accessed Apr. 6,2011

27. Chan A and Sage LC, Estimating Australia's abortion rates 1985-2003, Medical Journal of Australia, 2005, 182(9):447-452.

28. Evans A, Australian Demographic and Social Research Institute, Australian National University, Canberra, Australia, personal communication, Dec. 17, 2011.

29. Chan A et al., Pregnancy Outcome in South Australia 2008, Adelaide Australia: Pregnancy Outcome Unit, South Australia Health, Government of South Australia, 2009

30. Population Division, UN Department of Economic and Social Affairs, World fertility patterns 2009 wall chart, New York: UN, 2010

31. Population Division, UN Department of Economic and Social Affairs, World Contraceptive Use 2009, New York: UN, 2009.

32. Statistics Canada, Induced Abortion Statistics 2005, Ottawa, Canada: Statistics Canada, 2008, <http://www.statcan.gc.ca/pub/82-223-x/ 82-223-x2008000-eng.pdf>, accessed Apr. 5, 2011. 
33. Canadian Institute for Health Information, Therapeutic abortions data 2008, no date, <http://www.cihi.ca/CIHI-ext-portal/pdf/ internet/ TA_08_ALLDATATABLES20101124_EN>, accessed Apr. 5, 2011.

34. Zheng X et al., Pregnancy and access to abortion of unmarried women aged 15-24 in China, paper presented at the annual meeting of the Population Association of America, Washington, DC, Mar. 31Apr. 2, 2011.

35. Gu B, Induced abortion in China, paper presented at the annual meeting of the Population Association of America, Dallas, TX, USA, Apr. 15-17, 2010

36. Yang J, Triple disadvantages: economic integration of post-80 born rural-to-urban migrants to the host society in China, paper presented at the IUSSP Seminar on Youth Migration and Transitions to Adulthood in Developing Countries, Rio de Janeiro, Brazil, Dec. 8-10, 2010.

37. Sohn A and Chun SS, Gender differences in sexual behavior and condom-related behaviours and attitudes among Korean youths, AsiaPacific Journal of Public Health, 2007, 19(2):45-52.

38. Sun TH, Planned Parenthood of Taiwan, Taipei, personal communication, Aug. 27, 2010.

39. Hoang KD and Xuan LTT, Induced abortion rates in Vietnam: the problems of measurement methods, paper presented at the IUSSP International Seminar on Measurement of Abortion Incidence, Abortion-Related Morbidity and Mortality, Paris, Nov. 7-9, 2007.

40. Nguyen QA and Hoang KD, Induced abortion in Vietnam: fact and resolution, paper presented at the Committee for International Cooperation in National Research in Demography International Seminar on Reproductive Health, Unmet Needs and Poverty, Bangkok, Nov. 25-30, 2002.

41. Ghuman S et al., Continuity and change in premarital sex in Vietnam, International Family Planning Perspectives, 2006, 32(4): 166-174.

42. Armenia National Statistical Service, Armenia Ministry of Health and ORC Macro, Armenia Demographic and Health Survey 2005, Calverton, MD, USA: Armenia National Statistical Service, Armenia Ministry of Health and ORC Macro, 2006.

43. Azerbaijan State Statistical Committee and Macro International, Azerbaijan Demographic and Health Survey 2006, Calverton, MD, USA: Azerbaijan State Statistical Committee and Macro International, 2008.

44. Gran M, Interrupción voluntaria de embarazo y anticoncepción: dos métodos de regulación de la fecundidad Cuba 1995-2000, Havana, Cuba: Escuela Nacional de Salud Pública, Ministerio de Salud Pública, 2004.

45. Henshaw SK and Vargas YA, Study of induced abortion in Puerto Rico, 2001-2002, paper presented at the Saludpromujer Seminario Actualidad del Aborto en Puerto Rico y el Mundo: Hallazgos de la Segunda Encuesta Nacional de Aborto, San Juan, Puerto Rico, Jan. 22, 2003.

46. Eltigani EE, Toward replacement fertility in Egypt and Tunisia, Studies in Family Planning, 2009, 40(3):215-226.

47. Juarez F et al., Estimates of induced abortion in Mexico: What's changed between 1990 and 2006? International Family Planning Perspectives, 2008, 34(4):158-168.

48. Fetters $T$ and Samandari G, An estimate of safe and unsafely induced abortion in Cambodia, paper presented at the XXVI International Population Conference of the IUSSP, Marrakech, Morocco, Sept. 27-Oct. 2, 2009.

49. Sheriar NK, Making abortion safer in India by medical abortion, paper presented at the 2009 World Congress of the International Federation of Gynecology and Obstetrics, Cape Town, South Africa, Oct. 4-9, 2009.

50. Pant PD et al., Investigating Recent Improvements in Maternal Health in Nepal: Further Analysis of the 2006 Nepal Demographic and Health Survey, Calverton, MD, USA: Macro International, 2008.

51. Singh $S$ et al., The estimated incidence of induced abortion in Ethiopia, 2008, International Perspectives on Sexual and Reproductive Health, 2010, 36(1):16-25.

52. Harries J, Stinson K and Orner P, Health care providers' attitudes towards termination of pregnancy: a qualitative study in South Africa, BMC Public Health, 2009, Vol. 9, Art. 296, <http://www.biomedcentral. com/1471-2458/9/296>, accessed Apr. 6, 2011.

53. Shah I and Aahman E, Unsafe abortion in 2008: global and regional levels and trends, Reproductive Health Matters, 2010, 18(36): 90-101.

54. Sato R and Iwasawa M, Contraceptive use and induced abortion in Japan: How is it so unique among the developed countries? Japanese Journal of Population, 2006, 4(1):33-54.

55. Jones RK, Finer LB and Singh S, Characteristics of U.S. Abortion Patients, 2008, New York: Guttmacher Institute, 2010

56. U.S. Census Bureau, Foreign-born population of the United States: Current Population Survey, March 2008, Table 1.1, <http://www. census.gov/population/www/socdemo/foreign/cps2008.html>, accessed Apr. 6, 2011.

57. Government Statistical Service, Abortion statistics, England and Wales: 2009, Statistical Bulletin, London: Office for National Statistics and Department of Health, 2010, No. 1, <http://www.dh.gov.uk/ prod_consum_dh/groups/dh_digitalassets/documents/ digitalasset/dh_116336.pdf>, accessed Feb. 18, 2011.

58. International Planned Parenthood Federation (IPPF) European Network, Abortion Legislation in Europe, Brussels, Belgium: IPPF European Network, 2007.

59. Sedgh $G$ et al., Induced abortion: estimated rates and trends worldwide, Lancet, 2007, 370(9595):1338-1345.

60. Marston C and Cleland J, Relationships between contraception and abortion: a review of the evidence, International Family Planning Perspectives, 2003, 29(1):6-13.

61. Westoff CF, Recent trends in abortion and contraception in 12 countries, DHS Analytical Studies, Calverton, MD, USA: ORC Macro, 2005, No. 8.

\section{RESUMEN}

Contexto: La última vez en que se evaluó la incidencia del aborto legal en el mundo fue en 2003. Las evaluaciones periódicas de la incidencia del aborto son esenciales para monitorear las tendencias del embarazo no planeado y las brechas en la disponibilidad de los servicios anticonceptivos y el uso de ellos.

Métodos: En 2008, se compilaron estadísticas y estimaciones de abortos inducidos legales para 64 de los 77 países en los que el aborto legal generalmente está disponible. (De estos 77 países, 36 están en vías de desarrollo). Los 64 países en el análisis albergan al 98\% de las mujeres en edades de 15-44 que viven en los países elegibles para inclusión en el análisis. Las fuentes de datos incluyeron informes o cuestionarios respondidos, provenientes de oficinas nacionales de estadísticas y de encuestas representativas a nivel nacional. Expertos nacionales y regionales evaluaron qué tan completas estaban las cifras oficiales. También se evaluaron las tendencias a través del tiempo (es decir, entre los tres años para que disponemos de datos1996, 2003 y 2008).

Resultados: En 2008, en los 25 países que cuentan con registros completos (todos países desarrollados), las tasas de aborto variaron desde siete por 1,000 mujeres en edades de 15-44 (Alemania y Suiza) hasta 30 por 1,000 (Estonia). Las tasas de aborto disminuyeron entre 1996 y 2008 en la mayoría de los 20 países que cuentan con información consistentemente confiable. Las disminuciones generalmente fueron más pronunciadas que los aumentos, aunque el ritmo de la disminución se hizo más lento después de 2003. Las más altas tasas de abor- 
to ocurrieron en los países en desarrollo con estimaciones incompletas. Para la mayoría de los países en desarrollo con leyes liberales, las tasas de aborto estaban incompletas y variaban considerablemente.

Conclusiones: Las actuales altas tasas de aborto en algunos países, así como los pequeños aumentos en las tasas en otros, indican una gran necesidad de servicios de planificación familiar más efectivos para estas poblaciones. En muchos países se carece de los sistemas confiables de recolección de datos necesarios para asegurar que las tendencias sean monitoreadas de manera efectiva.

\section{RÉSUMÉ}

Contexte: L'évaluation périodique de l'incidence de l'avortement est essentielle au suivi des tendances de la grossesse non planifiée et des lacunes des services et de la pratique de la contraception.

Méthodes: Les statistiques et estimations des IVG légales pratiquées en 2008 ont été compilées pour 64 des 77 pays où l'avortement légal est généralement accessible; ces 64 pays sont ceux de $98 \%$ des femmes de 15 à 44 ans vivant dans les pays admissibles à l'inclusion. Les sources de données sont les rapports ou questionnaires complétés des offices nationaux de la statistique et d'enquêtes nationalement représentatives. La complétude des chiffres officiels a été évaluée par des experts internes aux pays et régionaux. Les tendances depuis 1996 et 2003 sont évaluées. Résultats: Des 77 pays dotés d'une législation libérale sur l'avortement, 36 font partie du monde en développement. En 2008, les taux d'avortement des 25 pays disposant d'une do- cumentation complète-tous pays développés-variaient entre sept (Allemagne et Suisse) et 30 (Estonie) pour 1.000 femmes âgées de 15 à 44 ans. Les taux d'avortement sont en déclin dans la majorité des 20 pays disposant d'une information régulièrement fiable sur les tendances entre 1996 et 2008; les baisses sont généralement plus fortes que les hausses, bien que le rythme du déclin diminue après 2003. Les plus hauts taux d'avortement observés le sont dans les pays en développement dont les estimations sont incomplètes. Pour la plupart des pays en développement dotés de législations libérales, les taux d'avortement déclarés sont incomplets et varient largement.

Conclusions: Les hauts taux d'avortement relevés dans certains pays et la faible augmentation des taux constatée dans d'autres révèlent un besoin important de services de planification familiale plus efficaces aux populations concernées. Les systèmes de collecte de données fiables nécessaires à l'assurance du suivi correct des tendances font défaut dans de nombreux pays.

\section{Acknowledgments}

The authors thank Evert Ketting for helping to obtain data, procuring and providing assessments of data quality, and reviewing a draft of this article, and Alyssa Tartaglione and Rubina Hussain for their extensive help with data collection and data management. We gratefully acknowledge support for this project from the United Kingdom Department for International Development, the Dutch Ministry of Foreign Affairs and the John D. and Catherine T. MacArthur Foundation.

Author contact: gsedgh@guttmacher.org 


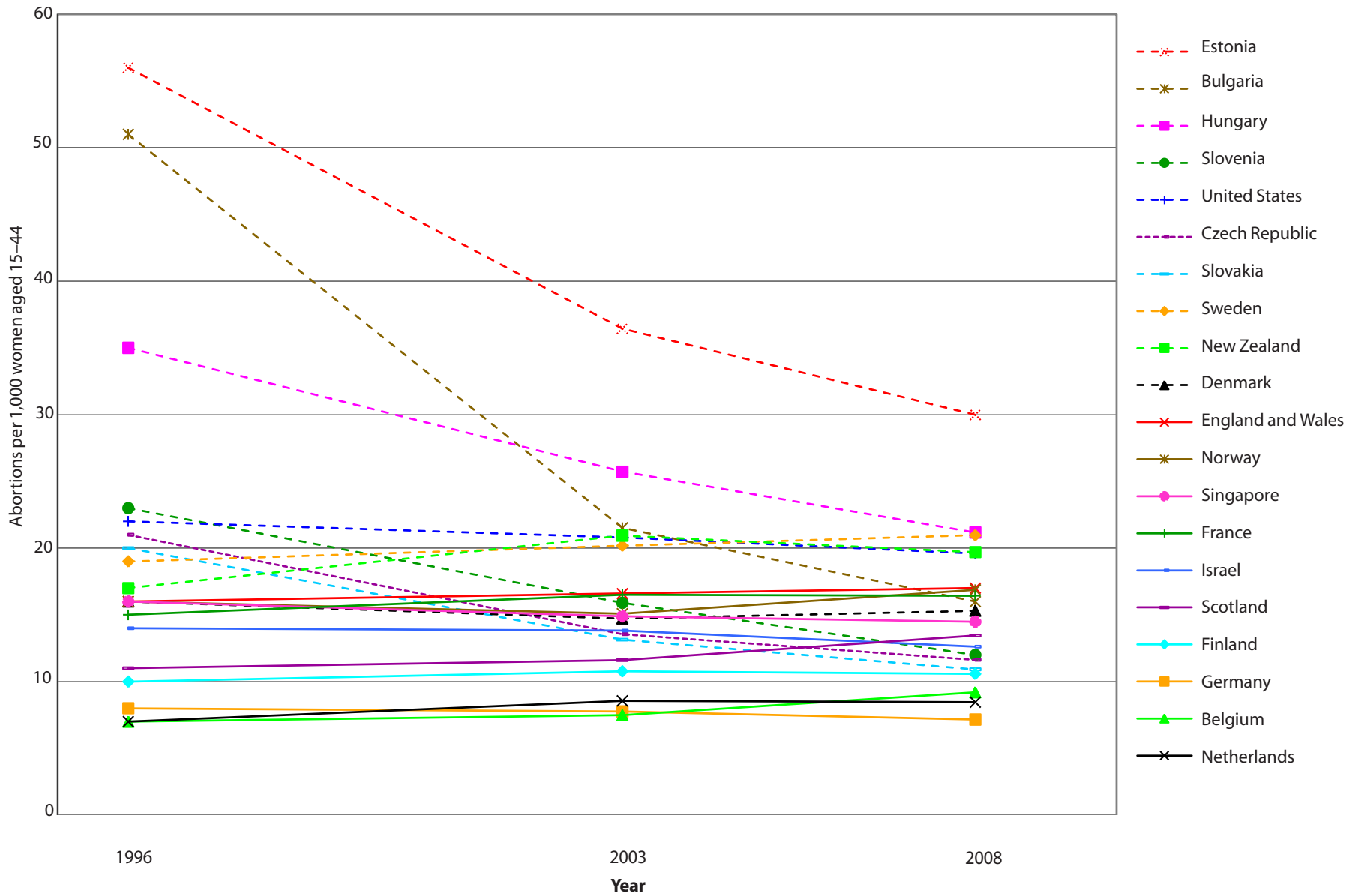

